IRA-International Journal of Management \&

Social Sciences

ISSN 2455-2267; Vol.17, Issue 04 (Q.4 2021)

Pg. no. 130-144.

IRA Academico Research

\title{
Capital Structure and Performance of Deposit Money Banks in Nigeria
}

\section{Osareme Erhomosele}

Department of Accounting, Faculty of Management Sciences, University of Jos, Nigeria.

Type of Work: Peer Reviewed.

DOl: https://dx.doi.org/10.21013/jmss.v17.n4.p4

\section{How to cite this paper:}

Erhomosele, O. (2021). Capital Structure and Performance of Deposit Money Banks in Nigeria. IRAInternational Journal of Management \& Social Sciences (ISSN 2455-2267), 17(4), 130-144.

DOI: https://dx.doi.org/10.21013/jmss.v17.n4.p4

(c) IRA Academico Research.

This full-text of this paper is available under Open Access subject to a Creative Commons Attribution-NonCommercial 4.0 International License $-\vec{T}$ and further subject to a proper citation of its primary publication source.

Disclaimer: The scholarly papers as reviewed and published by IRA Academico Research are the views and opinions of their respective authors and are not the views or opinions of IRA Academico Research. IRA Academico Research disclaims any harm or loss caused due to the published content to any party.

IRA Academico Research is an institutional publisher member of Publishers International Linking Association Inc. (PILA-CrossRef), USA. Being an institutional signatory to the Budapest Open Access Initiative, Hungary, the content published by IRA Academico Research is available under Open Access. IRA Academico Research is also a registered content provider under Open Access Initiative Protocol for Metadata Harvesting (OAl-PMH).

This paper is peer-reviewed following IRA Academico Research's Peer Review Program $[$ T.

Osareme Erhomosele [D/0000-0003-1757-357X[] 


\begin{abstract}
Investigations into the relationship between capital structure and firm performance over the years have consistently produced mixed results in the light of prevailing theories relevant to the concept of capital structure. The study examined the nature of the relationship between the capital structure of Deposit Money Banks (DMBs) in Nigeria and the trend of performance recorded in the industry. Leverage was adopted as a surrogate for capital structure, while firm performance was proxied by profit efficiency and return on equity. A regression analysis test was applied to a balanced panel data, pooled from a sample of 11 DMBs to determine the impact of capital structure on performance. The study found evidence that supports a non-monotonic relationship between capital structure and performance of DMBs, as predicted by the agency cost theoretical model. A major recommendation elicited from the findings of the study advocates for legal control on the proportion of debt DMBs can include in their capital structure if they are to operate as efficiently as expected.
\end{abstract}

ABSTRACT

Keywords: Finance, Deposit Money Banks, Capital Structure, Performance, Profit Efficiency, Nigeria, Agency cost, Firm performance.

\title{
1. INTRODUCTION
}

The capital structure dilemma is arguably the most popular item of discussion in finance cycles. Since the days of Modigliani and Miller, study after study has taken various viewpoints on how the capital structure perplexity should be addressed. The nature and workings of the capital structure phenomenon are more dynamic than it is static.

Fundamentally, the capital structure of any firm describes the mix of debt and equity used to finance the operations of the firm (Shubita et al., 2012). However, in practice, the capital structure phenomenon is not just about debt and equity (Brealy et al., 2001). It is a mix of different securities (Abor, 2005). Various alternatives and combinations exist from which the firm can choose (Shubita et al., 2012). Lease financing, warrants, convertible bonds, forward contracts or trade bond swaps; amongst others, are examples of such alternatives (Abor, 2005).

While managers retain discretion in choosing between debt and equity to finance the assets of the firm, they must make that choice with an informed perspective on how such a decision may affect the performance of the firm (Githire, 2015). This position becomes even more critical because there is a dearth of capital in developing countries; a challenge that drives firms to seek optimal ways of combining available debt and equity to either maximize shareholder wealth or to minimize Weighted Average Cost of Capital (WACC) or both (Ganiyu, 2015). The dependence of firms on the capital market to raise capital has continued to grow; given the explosion in liberalization and globalization of the global financial market (Azhagaiah \& Gavoury, 2011).

The banking industry is a vital and indispensable part of any economy. This is evidenced in the critical attention paid to the banking business by national governments. While various financial intermediaries are involved in funding the real sector of any economy, banks remain the most important of this group of institutions (Velnampy \& Niresh, 2012). Banks are profit-oriented organizations with the major objective of growing shareholder value. The nature of banking activities and the attendant regulatory guidelines require massive capital investment.

Consequently, in order to gauge the performance level of banks, the matter of capital structure inevitably becomes prominent. It is no coincidence that the banking sector in Nigeria has undergone a series of consolidation exercises; with the bane of such exercises hinged on the capital structure of the banks. Despite these efforts, Nigerian banks continue to remain an endangered species, evidenced in the high risk of corporate failure within the industry; Diamond bank PLC being the most recent case in point.

\subsection{Background to the study}

The consolidation of the Nigerian banking sector in 2004/2005 was precipitated by the abuse of controlling powers by managers and top executive directors. It was quite obvious that banks were run purely for the self-serving interests of managers, to the detriment of shareholders and depositors. The major thrust of the consolidation exercise was the capitalization of Nigerian banks. Implying that of all the items on the consolidation agenda, the capital structure of banks was given the most attention. This was to be expected, as the subject of bank capital has been a major component of banking reforms in Nigeria since 1952 (Okoye et al., 2017). 
Reforms in the banking industry are aimed at developing a diversified, strong and reliable banking sector. The Central Bank of Nigeria (CBN), in 2004, reviewed upward capital requirement for Nigerian banks, from two billion ( $\$ 2$ billion) naira to twenty-five billion ( $\$ 25$ billion) naira; thus, constraining banks to borrow funds to finance their operations (Shaba et al., 2016). The number of DMBs fell from 89 to 25 after the consolidation exercise; suggesting that some kind of relationship exist between capital structure and firm value/performance. In addition, several stringent regulatory requirements were put in place to forestall a reinvention of the pre-consolidation era, where the powers and opportunistic behaviour of managers were left untamed.

\subsection{Problem statement}

Several studies have been conducted on the impact of capital structure on banks' performance in developed countries. However, studies in developing countries remain insignificant when compared with those that have been carried out in developed countries. The significance in stating this fact lies in numerous differences that exist in the financial, microeconomic and regulatory environments between the two groups of countries.

Furthermore, there is evidence to suggest that the nature of capital structure in the banking industry differs significantly from those of other industries. This is due to the nature of the banking business and its pivotal role in the national, regional and global financial system. The consolidation exercise may have had an overall positive effect, especially on bank capitalization, however, its impact on the performance of DMBs has been more difficult to discern (Hassan and Miko, 2016); thus, raising questions about the relationship between capital structure and performance of DMBs.

\subsection{Study Objectives}

The study is primarily an investigation into the nature of the relationship between leverage and performance of listed DMBs in Nigeria. The specific objectives of this study are:

1. To determine if a significant relationship exists between leverage and profit efficiency of listed Deposit Money Banks in Nigeria.

2. To determine if a significant relationship exists between leverage and return on equity of listed Deposit Money Banks in Nigeria.

\section{CONCEPTUAL REVIEW}

\subsection{Concept of capital structure}

Financial management in firms is concerned with basically three major decisions. These decisions include financing decisions, investment decisions and dividend decisions (Vijayakumar \& Karunaiathal, 2014). Capital structure decision is the primary agenda of the financing aspect of financial management. Capital structure points out how the assets of the firm are financed (Nwaolisa \& Chijindu, 2016). It refers to the ratio between the debt and equity finance of the firm. Capital structure is often referred to as leverage, reflecting a comparison between the contributions of owners and those of creditors to financing the firm. The term financial structure is also used interchangeably with the term capital structure in finance literature (Idode et al., 2014).

Pandey (2010) defined capital structure as the several alternatives for financing a firm, that is, the proportionate interaction between debt and equity. Modugu (2013) asserts that the financial structure of a firm consists of various sources, which are presented in the equity and liability side of the balance sheet. Capital structure defines the ratio between owned capital and borrowed capital (Nwaolisa \& Chijindu, 2016). Abor (2005) and Esiemogie et al., (2014) define capital structure as the mix of debt and equity that a company uses to finance its business. In the view of Saad (2010) capital structure connotes the way a corporation finances its assets, through some combination of equity, debt or hybrid securities.

It is the benefits and costs attached to using debt finance that makes the capital structure debate a significant agenda in financial cycles. Although there is the tax shield benefit from using debt finance, this benefit must be balanced against the cost of using debt- the agency cost and the bankruptcy cost (Abor, 2005). Bankruptcy costs are the costs tied to the perceived probability that the firm will default on financing its debt. More debt means a higher risk of bankruptcy. Bankruptcy costs may be direct, such as the legal and administrative cost involved in the bankruptcy process; or indirect, such as loss of business with stakeholders. Agency cost, on the other hand, according to Company et al., (1976), arises from the conflicts inherent in the relationships between managers and shareholders and those between shareholders and providers of debt finance. 
Table I: Debt vs. Equity

\begin{tabular}{lll}
\hline Criteria & Debt & Equity \\
\hline Source & Creditors/ debt holders & Owners/ stockholders \\
Management influence & $\begin{array}{l}\text { Creditors have no influence on } \\
\text { management except in case of } \\
\text { special provisions }\end{array}$ & $\begin{array}{l}\text { Owners have influence over } \\
\text { their voting rights }\end{array}$ \\
Repayment & Debt has maturity date & Stock has no maturity date \\
Yearly obligations & $\begin{array}{l}\text { Firm has obligation to pay debt } \\
\text { interest annually }\end{array}$ & $\begin{array}{l}\text { Firm is not legally bound to pay } \\
\text { dividend }\end{array}$ \\
Tax benefits & Debt interest is tax deductible & Dividends are not tax deductible \\
\hline
\end{tabular}

Source: Author's compilation (2019)

\subsubsection{Determinants of capital structure}

The proportion of debt to equity which a firm maintains in its capital structure varies over time. These variations may occur as a result of deliberate action by a firm's managers. At other times, these variations occur due to a combination of circumstances that the firm has dealt with in the past or is currently seeking to adjust to. Empirical studies have studied various factors that affect a firm's capital structure. Huang and Song (2002) state that there is empirical backing for determinants of firm capital structure such as; profitability, tangibility, tax, size, non-debt tax shields, growth opportunities and volatility. Studies in Nigeria have thus gone on to include such factors in their methodologies when carrying out capital-related studies.

A relevant classification of these factors in current literature classifies them into two distinct but related groups. They are distinct because they can be identified and separated. They are related because they have been found to interact with each other. Thus, determinants of capital structure are either firm-specific or industryspecific (Bokpin \& Arko, 2009; Hackbarth et al., 2006; Öztekin \& Flannery, 2012)

Firm-specific factors are factors influencing the capital structure of the firm due to the peculiarities of the internal business environment of the firm. Meanwhile, country-specific factors are mostly economic in nature. They are those determinant factors that originate from outside the firm. They are external to the operating business environment of the firm. Such factors are beyond the control of the firm.

Jong et al. (2008) provide empirical evidence on how country-specific factors influence the capital structure of the firm. On the one hand, they influence leverage directly. According to them, an example would be where a more developed bond market facilitating issue and trading of public bonds may lead to the use of higher leverage in a country, while a less developed stock market will have the opposite effect. Conversely, country-specific factors influence corporate leverage indirectly through their interaction with firm-specific factors. Again Jong et al. (2008) built on the foregoing cited scenario. Although the developed bond market of a country stimulates the use of debt, the role of asset tangibility as collateral in borrowing will be rather limited for firms in the same country. Consequently, country characteristics may explain why in one country a firm's tangibility affects leverage, but not in another country.

The work of Jong et al. (2008), may have provided support for the argument put forward by Frank and Goyal, (2003). They argue that the firm-specific factors only account for $30 \%$ of the factors that determine the capital structure choice of firms. Similarly, Bokpin (2009), concludes that country-specific factors account for $70 \%$ of the influence on capital structure. This supports the claim by Jong et al. (2008) of a two-fold effect on the capital structure by country specific-factors. Consequently, it may be interesting to note the assertion of Ganiyu (2015). He argues that a bulk of past theoretical and empirical studies have often ignored country factors as variables that account for the financing choice of firms and have instead, paid more attention to firmspecific factors.

Pandey (2010), on his part, makes a case for factors that he believes affect capital structure decisions in practice, even in the absence of empirical measurements and/ or theoretical proofs. He states that such factors include; business risk, nature of the firm's assets, growth rates of the firm, stability of sales, profitability, taxes, control, management attitudes, lender and rating agency attitudes, conditions in the stock market, perceived 
undervaluation of equity shares in the Stock market, and reserve borrowing capacity. His position is supported by (Olowe, 2011).

\subsubsection{Industry differences in capital structure}

When studies on capital structure are conducted on a countrywide basis, the results reflect only a net effect. Such an approach inevitably hides the peculiarities of the various segments of the economy. A more detailed and significant approach will be to carry out industry analysis. Results from such studies provide valuable and practical insights on the behaviour of leverage trimmed by distinctive attributes of various industries. There is no shortage of evidence to support claims of significant differences in the capital structure (Bradley, et al., 1984). The volume of the cost incurred on fixed assets (Brigham \& Houston, 2007), the debt ratio (Guney et al., 2011), preconditions for access to capital (Balakrishnan and Fox, 1993), and many other industry-related factors affect the capital structure decisions of the firm (Bradley et al., 1984; Harris and Raviv, 1991; Kovenock and Phillips, 1995; Morri and Cristanziani, 2009)

According to Hassan and Sandy (2015), industry differences are explained by the fact that companies operating in the same industry have many similarities and operate in the same environment where they face similar challenges, competition, risks, technology, profitability and regulations. While capital structure literature is awash with studies establishing frameworks for the country and firm-specific factors (Erotis et al., 2011; Jong et al., 2008; Psillaki and Daskalakis, 2009); very little has been done to harmonize industry-related factors. In the view of Mirza and Javed (2013), industry differences are influenced by both internal and external factors; however, internal factors account for a greater proportion of those differences.

According to Buser (1981), cited in Velnampy and Niresh (2012), the capital structure decision of a bank is similar to that of a nonfinancial firm. However, significant differences in the capital structure exist due to the unique nature of each industry's business and the intra-firm variations attributed to the business and financial risk of the individual firm. According to Esiemogie et al. (2014), The banking sector in most economies is so critical that it attracts much attention from the domestic financial institutions, governmental regulatory authorities and international institutions.

In the view of Barth et al. (2004) banks, in general, operate under a unique and rigorous set of regulations that only apply to that sector, making it impossible to explain the relationship of both the banking market and the rest of the market using only a single model or indeed a single dataset. One major peculiarity is that banks do not have a clear cut classification of what constitutes short term debt and what obligations fall within the definition of long term debt.

\subsection{Concept of firm performance}

The concept of performance is subjective as there are various measures of firm performance. Performance measures may assess areas such as profitability, liquidity, efficiency, investment attractiveness, and so on. How researchers choose to measure performance is dependent on the objective of their studies, empirical backing from extant literature and preferred theoretical underpinning. However, in practice, firms select performance measures in line with corporate strategic objectives and general industry standards.

Performance indicators are the tools by which the performance of a firm is measured. Corporate firms have a multiplicity of stakeholders. While managers may feel that their primary responsibility is to maximize the wealth of shareholders, a strategic approach suggests that firm performance must be a holistic agenda, in other to ensure that the firm truly accomplishes its mission and vision. An attempt to ignore other stakeholders of the firm may prove disastrous, and probably render any goals of benefiting from an optimal capital structure unreachable.

Empirical studies investigating the impact of capital structure on the firm performance have traditionally focused on the profitability perspective of performance, thus benchmarks such as return on assets (ROA), return on equity (ROE), net profit margin, gross income, return on capital employed (ROCE), earning per share (EPS), and so on; have continued to appear in literature as surrogates for firm performance. This may be explained by the fact that firms maintain a profit-driven motive. Consequently, all other areas of performance may only be relevant to the extent that they contribute to the profitability of the firm. Nonetheless, performance within the banking sector involves much more than profitability. Profitability is the ability of a firm to generate net income consistently. Ratios have been instrumental in communicating firm profitability. According to Velnampy and Niresh (2012), Ratios help to summarize large quantities of financial data and to make a qualitative judgement about the firm's profitability. 
Being service providing institutions, Banks must measure much more than profit. Qualities such as efficiency, economy and effectiveness need to be put into consideration. The point therefore is that firm success is not predicated on a one-sided approach. Thus, between capital structure and profitability, lies other performance metrics that banks cannot afford to ignore.

\section{THEORETICAL REVIEW}

Capital structure theory dates back to the seminal work of Modigliani \& Miller (1958) before which very little was known about capital structure (Dada, 2014; Githire, 2015). Modigliani and Miller (MM) postulated that the value of a firm is not dependent on its capital structure; thus, also implying that there was no relationship whatsoever between capital structure and firm performance. The MM theory was based on certain assumptions, whose criticisms later paved way for the development of modern theories of capital structure. These assumptions suggested perfect capital market conditions. The theory assumed that frictions such as; taxes, bankruptcy costs, agency costs, transactions costs, and asymmetric information were non-existent.

Although the MM theory provided an in-road into understanding capital structure, its assumptions of an efficient capital market could not hold for long. The theory was only valid if these assumptions were upheld (Gwatidzo, 2009). Such assumptions, at best, were idealistic, and in no way reflected the real-world situation. Despite relaxing the assumption of no tax (Modigliani \& Miller, 1963), the MM theory still lacked any realistic outlook. Thus, other theories of capital structure; such as trade-off theory, pecking order theory, market timing theory, and agency cost theory, amongst others; were developed to take into cognizance the drawbacks of the MM theory.

\subsection{Agency cost theoretical model}

The agency cost approach to capital structure thrives on the perceived lack of attention by other theories of capital structure to the conflict that arises when ownership is separated from control; as is the case in corporations. Ganiyu (2015) considers the theory to be an extension of the trade-off theory. The Agency cost theoretical model was popularized by Jensen and Meckling (1976). It argues that managers will not always act in the best interest of shareholders, even though, that is the expectation. Managers are likely to be self-serving to the detriment of the shareholders. This friction gives rise to agency conflicts.

According to Jensen (1986), there are two main advantages the firm enjoys by employing debt in its capital structure. Firstly, the firm uses debt to discipline managers (Shaba et al., 2016). Higher debt reduces the free cash flow that managers can use for self-seeking outlays. They become focused on meeting debt obligations for the fear of bankruptcy of the firm. Bankruptcy will inevitably lead to the loss of jobs of the managers or their shareholding, as the case may be. Consequently, they strive to maximize the value of the firm through improved performance (Ganiyu, 2015). The second advantage is the tax shield enjoyed by the firm. This arises because debt interest is tax-deductible. The tax savings could be employed in profitable investments, thus raising the value of the firm. From the foregoing, the agency cost theoretical model, therefore, predicts a positive relationship between leverage and firm performance.

A further twist in the agency cost theoretical model relates to the prediction that there could be a negative relationship between leverage and firm performance. This situation arises when the focus of conflict shifts from that between managers and owners to the conflict of interest between debt holders and equity investors. Where there is an existing debt portion within the capital structure of the firm, there is always the inherent risk of default. The risk of default describes the risk that the firm may be unable to meet its obligations to debt holders in the future. This risk grows with the increasing use of debt by the firm. The agency cost theoretical model posits that the risk of default may lead to an underinvestment problem; where equity holders attempt to shift the business risks of the firm to debt holders, resulting in a conflict between debt holders and equity investors. The default risk thus represents a cost of debt rather than a benefit. Hence, a non-monotonic (positive relationship for small values and negative for large values of leverage ratios) relationship may arise between leverage and firm performance. 
Figure 1: Conceptual/theoretical framework

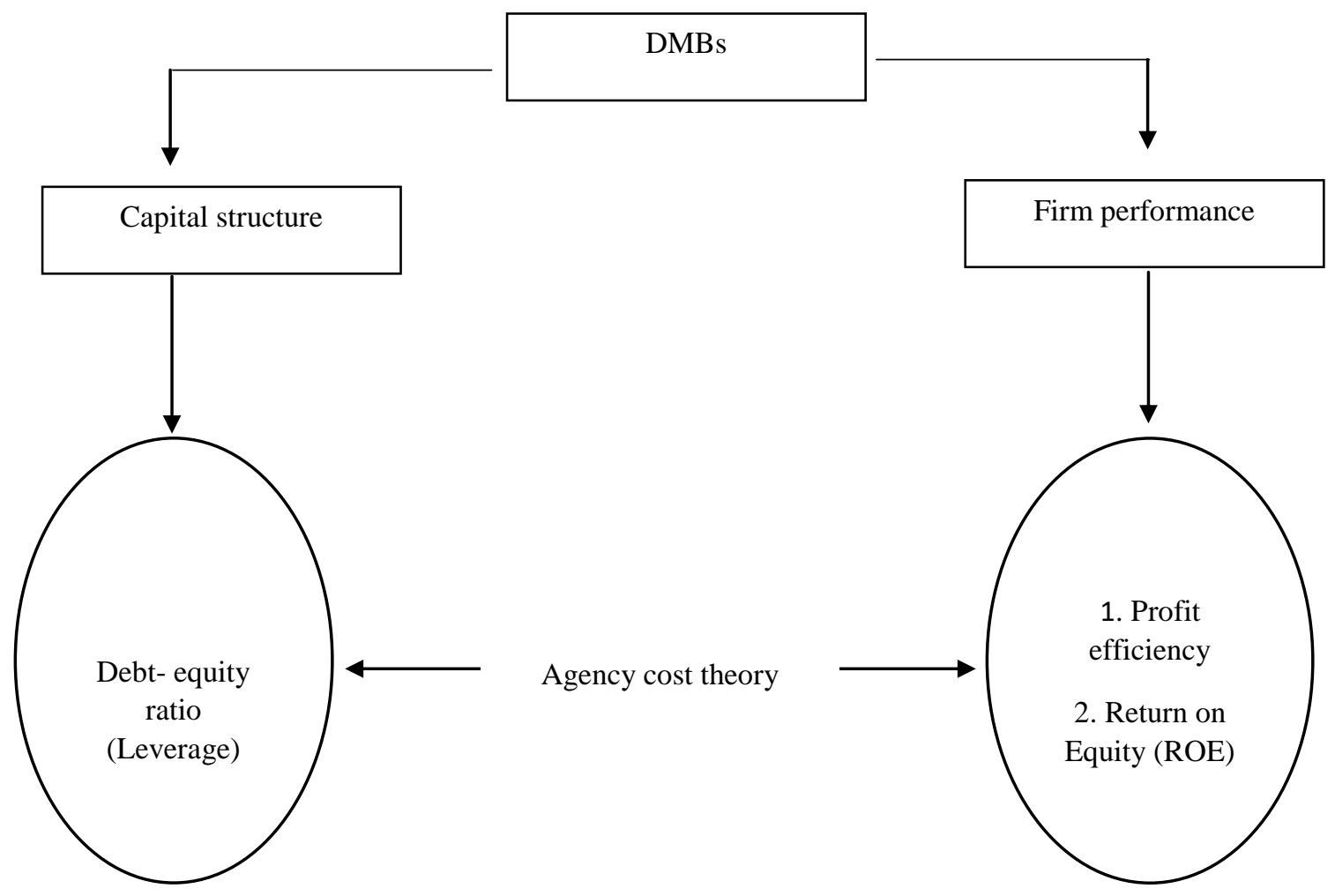

4. EMPIRICAL REVIEW

There is a large body of research on the subject of capital structure and how it impacts the performance of firms, both in developed and developing nations (Muturi, 2015). However, the results have been contradictory (Idode et al., 2014; Nwaolisa \& Chijindu, 2016). Following the work by Modigliani and Miller (1958), where they argue that financial leverage does not affect the firm's market value, based on assumptions such as homogenous expectations, perfect capital markets and no taxes; the pecking order theory (Myers \& Majluf, 1984) and the trade-off theory (Jensen, M. C.,\& Meckling, 1976) opposed the capital structure irrelevance proposition of Modigliani and Miller. In the aftermath, a majority of studies have found a relationship between capital structure, firm value and firm performance.

While some studies have shown evidence of a positive relationship between leverage and firm performance ( Esiemogie et al., 2014; Amin \& Jamil, 2015; Muturi, 2015; Shaba et al., 2016); other studies, such as Abor (2005), Zeitun and Tian (2007), found a negative empirical relationship between capital structure and firm performance. Studies by Bancel and Mittoo (2004); Jong et al. (2008); Psillaki and Daskalakis, (2009); Erotis, et al. (2011); have expanded to examine the firm and country determinants of capital structure.

Furthermore, as a result of the far-reaching implications of capital structure decisions, other studies have examined how it relates to other burning contemporary issues in the field of corporate finance, such as corporate governance ( Jiraporn \& Gleason, 2007; Bokpin and Arko, 2009; Butt and Hasan, 2009; Saad, 2010; Jiraporn et al., 2012; Morellec et al., 2012); earnings management ( Ali et al., 2008; Naz et al., 2011; Rahmani \& Akbari, 2013; An et al., 2016); and dividend policy (Aggarwal \& Kyaw, 2010; Mirza \& Azfa, 2010; AlNajjar, 2011).

An industry categorization perspective shows that investigations into the relationship between capital structure and firm performance have focused less on the banking and financial sectors. Thus, there is a dearth of literature on capital structure in the banking industry. However, studies such as Berger and Bonaccorsi (2006), Skopljak (2012), Velnampy and Niresh (2012), Esiemogie et al. (2014), Adesina et al. (2015), Shaba et al. (2016) specifically gave attention to examining the relationship between capital structure and performance in the banking sector.

Summarily, a relevant methodology for empirical review of studies on capital structure and firm performance in the banking sector may consist of a four-quadrant approach as shown in figure 2 . The four 
quadrants being an interaction between the criteria of industry (banking vs. non-banking business) and Economic (developed vs. developing economies)

Figure 2: A suggested framework for empirical review

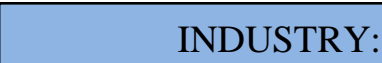

Banking vs Non- banking
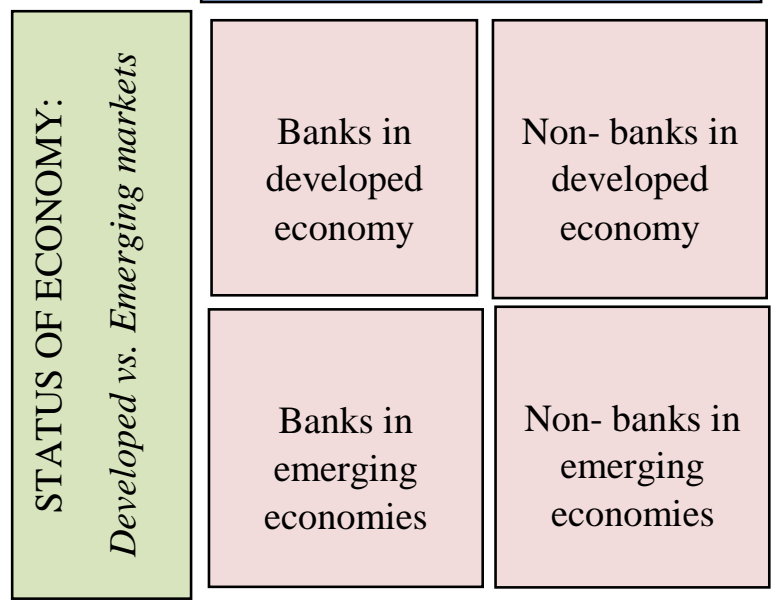

\section{METHODOLOGY}

\subsection{Method and data}

The study is based on an Ex-post facto research design. All hypotheses are tested at 1\%, 5\% and 10\% levels of significance. The population for this study comprises all 21 DMBs operating in Nigeria for the period 2011 to 2017. The study adopts a convenience sampling technique. The criteria for selection limit the sample size to banks whose shares are publicly traded on the electronic trading platform of the NSE and, whose financial statements were published for the period under consideration. Consequently, only 11 of the 16 listed banks were included in the final sample of the study based on the outlined criteria.

Table II: List of sampled Nigerian DMBs

\begin{tabular}{|l|l|}
\hline 1 & Access bank PLC \\
\hline 2 & Diamond Bank PLC \\
\hline 3 & Fidelity Bank PLC \\
\hline 4 & First Bank of Nigeria PLC \\
\hline 5 & First City Monument Bank PLC \\
\hline 6 & Guaranty Trust Bank PLC \\
\hline 7 & Sterling Bank PLC \\
\hline 8 & Union Bank PLC \\
\hline 9 & United Bank for Africa PLC \\
\hline 10 & Wema Bank PLC \\
\hline 11 & Zenith Bank PLC \\
\hline
\end{tabular}

Source: Author's compilation (2019) 
Data were obtained from the Annual reports of the selected banks. For research purposes, annual reports of companies remain the most reliable means by which companies communicate to stakeholders ( Wilmshurst and Frost, 2000; Stanton and Stanton, 2002; Holland and Foo, 2003). The requirement to audit the financial statements contained in the reports, coupled with various regulatory requirements for listed public companies, lends credence to the truth and fairness of such reports. Thus, such reports can be relied upon for objective and valid research data and assessment.

\subsection{Research hypotheses}

In line with the objectives of the study, the following hypotheses are proposed:

$\boldsymbol{H}_{\boldsymbol{I}}$ : There is no significant relationship between leverage and profit efficiency of listed Deposit Money Banks in Nigeria.

$\boldsymbol{H}_{2}$ : There is no significant relationship between leverage and return on equity of listed Deposit Money Banks in Nigeria.

\subsection{Data analysis}

Statistical analysis for this study comprises both descriptive and inferential statistical measures. The study employs both descriptive and inferential statistics in presenting and analyzing the data collected. The tests specified in carrying out the analyses of data in this study include; the Correlational analysis test and the Ordinary Least Square (OLS) regression test.

\subsubsection{Model specification}

\section{- $\quad$ Linear models}

The expectation according to the agency cost theory is that leverage should have a positive relationship with profit efficiency and return on Equity. The models are specified thus:

$$
\begin{aligned}
& P E F=\beta_{0}+\beta_{1} L E V_{i t}+\beta_{2} Z_{i t}+\varepsilon_{i t} \\
& R O E=\beta_{0}+\beta_{1} L E V_{i t}+\beta_{2} Z_{i t}+\varepsilon_{i t}
\end{aligned}
$$

Where PEF $=$ Profit Efficiency, ROE = Return on Equity, $\beta_{0}=$ Intercept, $\beta_{1}$ and $\beta_{2}=$ Coefficients of explanatory variables, and, $\varepsilon_{i}=$ stochastic error term. $\mathrm{Z}_{\mathrm{i}}=$ Vector of control variables believed to influence profit efficiency and return on equity (Firm size, tangibility, growth and risk)

- Non- monotonic models

The agency cost theory predicts that the use of debt can harm performance if excessively used. Based on this prediction, the study specifies the following models to test the non-monotonic relationship predicted by the agency cost theory.

$$
\begin{aligned}
& P E F F=\alpha_{0}+\alpha_{1} L E V_{i t}+\alpha_{2} L E V^{2}{ }_{i t}+\alpha_{3} Z_{i t}+\mu_{i t} \\
& R O E=\alpha_{0}+\alpha_{1} L E V_{i t}+\alpha_{2} L E V_{i t}^{2}+\alpha_{3} Z_{i t}+\mu_{i t}
\end{aligned}
$$

The parameters are as defined in (1) and (2). LEV ${ }^{2}$ is added in the specified models to test for the nonmonotony in the relationship between leverage and performance as implied by the agency cost theory. This approach is similar to those employed by Berger and Bonaccorsi (2006), Margaritis and Psillaki (2010) and, Skopljak (2012).

\section{Table III: Description of research variables}

\begin{tabular}{ll}
\hline Variable & Measurement \\
\hline Endogenous variables & Profit Efficiency__Skopljak, 2012) model \\
PEF & Return on Equity_Ratio of equity to total assets \\
ROE & \\
\hline Explanatory variables & Leverage_Ratio of total debt to total assets \\
LEV & Tangibility_Ratio of total fixed assets to total assets \\
TAN & Size_ Natural logarithm of total assets \\
SIZ & Risk_Standard deviation of return on equity \\
RSK & Growth_Percentage change in the log of total assets \\
GWT & Source: Author's compilation (2019)
\end{tabular}




\subsubsection{Profit efficiency}

Profit efficiency is the measure of output produced relative to a given amount of inputs (Skopljak, 2012). According to Berger and Bonaccorsi (2006) profit efficiency takes account of agency costs due to the difficulties and costs of identifying and removing managers with poor abilities, as well as, active decisions by managers to pursue different goals from shareholders and, by shareholders to pursue different objectives from debt holders. Thus, profit efficiency is a succinct representation of both manager-shareholder conflict and shareholder-debt holder conflict.

The premium of the profit efficiency measurement over popular accounting-based measures relates to the fact that it takes into account the actual performance of firms in the industry and the exogenous conditions under which the firms operate. Profit efficiency has been employed in several studies ( Maudos et al., 2002; Berger \& Bonaccorsi, 2006; Margaritis \& Psillaki, 2010; Skopljak, 2012).

Profit efficiency is derived using the model specified in Skopljak (2012). He asserts that the model maintains consistency with efficiency measures in previous papers and is suitable for a small sample size. The sample size employed in that study was 16 banks. This is similar to the sample size of 11 banks used in this study. The model is thus stated:

$P E F=\alpha+\ln \left(X 1_{i t}\right)+\ln \left(X 2_{i t}\right)+\ln \left(C 1_{i t}\right)+\ln \left(C 2_{i t}\right)+\ln \left(C 3_{i t}\right)+\ln \left(X 1_{i t} / C 1_{i t}\right)+\ln \left(X 1_{i t} / C 2_{i t}\right)+$ $\ln \left(X 1_{i t} / C 3_{i t}\right)+\ln \left(X 2_{i t} / C 1_{i t}\right)+\ln \left(X 2_{i t} / C 2_{i t}\right)+\ln \left(X 2_{i t} / C 3_{i t}\right)+\ln \left(P_{i t} / A_{i t}\right)+\ln \left(P_{i t}\right) / \ln \left(E_{i t}\right)$

Table IV: Variables for Profit Efficiency

\begin{tabular}{|c|c|c|}
\hline Input & Description & Definition/Measurement \\
\hline $\mathrm{C} 1$ & Cost of loaned funds & $\begin{array}{l}\text { This is defined as the interest expense divided by the corresponding } \\
\text { amount owing. The amount owing is computed by adding up the } \\
\text { liabilities of deposits and owing to other banks. }\end{array}$ \\
\hline $\mathrm{C} 2$ & Cost of labour & $\begin{array}{l}\text { The cost of labour is defined as the total amount spent on personnel } \\
\text { divided by the total number of employees at the bank. }\end{array}$ \\
\hline $\mathrm{C} 3$ & Cost of fixed assets & $\begin{array}{l}\text { The cost of fixed assets is defined as the cost on plant and equipment } \\
\text { divided by total fixed assets }\end{array}$ \\
\hline $\mathrm{X} 1$ & Revenue from loans & It is the net interest revenue from loans (in absolute values) \\
\hline $\mathrm{X} 2$ & $\begin{array}{l}\text { Revenue from other } \\
\text { activities }\end{array}$ & $\begin{array}{l}\text { It encompasses the net operating income from activities other than } \\
\text { interest revenue }\end{array}$ \\
\hline $\mathrm{P}$ & Profit after tax & \\
\hline $\mathrm{E}$ & Equity & \\
\hline A & Total assets & \\
\hline$\alpha$ & Model constant & $\begin{array}{l}\text { Added on to all the figures in order to standardize the inevitable } \\
\text { outlying negative values to positive ones. }\end{array}$ \\
\hline
\end{tabular}

\section{RESULTS}

6.1 Summary statistics

Table V: Descriptive Statistics

\begin{tabular}{lccccc}
\hline Variables & Obs. & Min & Max & Mean & Standard Dev. \\
\hline PEF & 77 & 91.3512 & 103.0264 & 98.0109 & 2.6949 \\
ROE & 77 & -0.1602 & 0.1824 & 0.0485 & 0.0557 \\
LEV & 77 & 0.0868 & 0.9948 & 0.8469 & 0.097 \\
LEV $^{2}$ & 77 & 0.0075 & 0.9896 & 0.7266 & 0.1092 \\
SIZ & 77 & 12.3066 & 15.4712 & 14.1575 & 0.7285 \\
TAN & 77 & 0.0128 & 0.0609 & 0.0318 & 0.0107 \\
GWT & 77 & -0.0083 & 0.0329 & 0.0072 & 0.0077 \\
RSK & 77 & 0.0051 & 0.0908 & 0.0345 & 0.0234 \\
\hline
\end{tabular}

Source: Results of author's computation: SPSS output (2019). 
A mean value of approximately 85\% (0.8466) for LEV reveals that Nigerian DMBs are highly levered institutions, as corroborated by Shaba et al. (2016). Thus, the capital structure of the banking industry in Nigeria is highly skewed towards debt finance. This may not be unconnected with the high reserve ratio requirement by the $\mathrm{CBN}$.

A comparison of the standard deviations of the dependent variables of PEF and ROE implies that both measures take significantly different approaches to measuring profitability, thus suggesting robustness to the results obtained from the regression models. In a similar vein, both variables maintain a strong significant positive relationship; implying that they may be valid measures of the same phenomenon; as well as, being influenced by similar factors.

Table VI: Pearson Correlation Matrix of Study Variables

\begin{tabular}{|c|c|c|c|c|c|c|c|c|}
\hline & $\mathrm{PEF}$ & ROE & LEV & $\mathrm{LEV}^{2}$ & SIZ & TAN & GWT & RSK \\
\hline PEF & 1 & & & & & & & \\
\hline ROE & $0.786^{* *}$ & 1 & & & & & & \\
\hline LEV & -0.069 & 0.019 & 1 & & & & & \\
\hline $\mathrm{LEV}^{2}$ & -0.142 & -0.034 & $0.964^{* * *}$ & 1 & & & & \\
\hline SIZ & $0.699^{* *}$ & $0.627^{* *}$ & -0.088 & -0.156 & 1 & & & \\
\hline TAN & $-0.359^{* *}$ & $-0.355^{* *}$ & -0.092 & -0.130 & $-0.467^{* *}$ & 1 & & \\
\hline GWT & 0.091 & $0.232^{*}$ & 0.088 & 0.100 & 0.069 & -0.135 & 1 & \\
\hline RSK & 0.139 & -0.097 & -0.147 & $-0.273^{*}$ & $0.282^{*}$ & $0.449^{* * *}$ & -0.080 & 1 \\
\hline
\end{tabular}

Source: Results of author's computation: SPSS output (2019).

Statistically significant relationships occur at 5\% and $10 \%$ significance levels across the matrix. Significant estimates, thus, makes a case for the relevance of explanatory variables included in the regression model.

\subsection{Inferential statistics}

Table VII: Regression Estimates for Linear Models

\begin{tabular}{|c|c|c|c|c|c|c|c|}
\hline & & De & ent Vari & PEF & Depe & nt Varia & ROE \\
\hline Model & VIF & $\beta$ & T- Stat. & Sig. & $\beta$ & T- Stat. & Sig. \\
\hline Constant & & & 8.260 & 0.000 & & -6.446 & 0.000 \\
\hline LEV & 1.039 & -0.018 & -0.206 & 0.837 & 0.041 & 0.496 & 0.621 \\
\hline SIZ & 2.106 & $0.718^{* * * *}$ & 5.858 & 0.000 & $0.880^{* * * *}$ & 7.486 & 0.000 \\
\hline TAN & 2.429 & 0.009 & 0.071 & 0.944 & $0.286^{* *}$ & 2.268 & 0.026 \\
\hline GWT & 1.026 & 0.039 & 0.457 & 0.649 & $0.170^{* *}$ & 2.077 & 0.041 \\
\hline RSK & 2.046 & -0.067 & -0.555 & 0.581 & $-0.454^{* * * *}$ & -3.917 & 0.000 \\
\hline & & R-Square & & 0.494 & R-Squarec & & 0.534 \\
\hline & & Adjusted & quared & 0.458 & Adjusted $\mathrm{R}$ & juared & 0.501 \\
\hline & & F- Stat. & & 13.845 & F- Stat. & & 16.277 \\
\hline & & Prob. (F- & & $<0.001^{* * * *}$ & Prob. (F- S & & $<0.001^{* * * *}$ \\
\hline & & Durbin $\mathrm{W}$ & & $0.775^{* *}$ & Durbin Wa & & $0.890^{* *}$ \\
\hline & & Obs. & & 77 & Obs. & & 77 \\
\hline
\end{tabular}

$\beta=$ standardized coefficients of regression; $* * * \quad=$ significant at $1 \%$ level of significance

$* *=$ significant at $5 \%$ level of significance; $*=$ significant at $10 \%$ level of significance

Source: Results of author's computation: SPSS output (2019). 
Table VIII: Regression Estimates for Non- monotonic Models

\begin{tabular}{|c|c|c|c|c|c|c|c|}
\hline \multirow{2}{*}{\begin{tabular}{|l|} 
Model \\
\end{tabular}} & \multirow[b]{2}{*}{ VIF } & \multicolumn{3}{|c|}{ Dependent Variable: PEF } & \multicolumn{3}{|c|}{ Dependent Variable: ROE } \\
\hline & & $\beta$ & T- Stat. & Sig. & $\beta$ & T- Stat. & Sig. \\
\hline Constant & & & 9.101 & 0.000 & & -6.457 & 0.000 \\
\hline LEV & 7.230 & $-0.389^{*}$ & -1.738 & 0.087 & $-0.396^{*}$ & -1.870 & 0.066 \\
\hline $\mathrm{LEV}^{2}$ & 7.070 & $-0.396^{*}$ & -1.792 & 0.077 & $-0.467^{* *}$ & -2.229 & 0.029 \\
\hline SIZ & 2.149 & $0.687^{* * * *}$ & 5.633 & 0.000 & $0.843^{* * * *}$ & 7.297 & 0.000 \\
\hline TAN & 2.432 & 0.001 & 0.007 & 0.995 & $0.276^{* *}$ & 2.247 & 0.028 \\
\hline GWT & 1.028 & 0.045 & 0.537 & 0.593 & $0.178^{* *}$ & 2.223 & 0.029 \\
\hline RISK & 2.306 & -0.143 & -1.133 & 0.261 & $-0.544^{* * * *}$ & -4.541 & 0.000 \\
\hline & & \multirow{6}{*}{\multicolumn{2}{|c|}{$\begin{array}{l}\text { R- Squared } \\
\text { Adjusted R- Squared } \\
\text { F- Stat. } \\
\text { Prob. (F- Stat.) } \\
\text { Durbin Watson } \\
\text { Obs. }\end{array}$}} & 0.516 & \multirow{6}{*}{\multicolumn{2}{|c|}{$\begin{array}{l}\text { R- Squared } \\
\text { Adjusted R- Squared } \\
\text { F- Stat. } \\
\text { Prob. (F- Stat.) } \\
\text { Durbin Watson } \\
\text { Obs. }\end{array}$}} & 0.565 \\
\hline & & & & 0.474 & & & 0.528 \\
\hline & & & & 12.433 & & & 15.151 \\
\hline & & & & $<0.001^{* * *}$ & & & $<0.001^{* * * *}$ \\
\hline & & & & $0.787^{* * *}$ & & & $0.940^{* *}$ \\
\hline & & & & 77 & & & 77 \\
\hline
\end{tabular}

$\beta=$ standardized coefficients of regression; $* * * \quad=$ significant at $1 \%$ level of significance

$* *=$ significant at $5 \%$ level of significance; $*$ = significant at $10 \%$ level of significance

Source: Results of author's computation: SPSS output (2019).

\subsection{Test of hypotheses}

\subsubsection{Hypothesis 1}

Based on the results in table 7, no significant linear relationship exists between leverage and profit efficiency ( $\mathrm{p}=0.837$ ). However, results reported in table 8 show that the p-value of the coefficient of $\mathrm{LEV}^{2}$ is negative and statistically significant at a $10 \%$ level of significance. Thus, there is a significant non-monotonic relationship between leverage and profit efficiency. Consequently, the study rejects the Null hypothesis and accepts the Alternative hypothesis of a significant relationship between leverage and profit efficiency of listed DMBs in Nigeria.

\subsubsection{Hypothesis 2}

The linear relationship between ROE and LEV, in table 7, is observed to be positive, albeit, this relationship is not significant at any level of significance $(\mathrm{p}=0.496)$. Conversely, the results in table 8 support a non-monotonic relationship between leverage and return on equity $(\mathrm{p}=0.029)$, at a $5 \%$ level of significance. Based on the results obtained, the study thus rejects the Null hypothesis and accepts the Alternative hypothesis of a significant relationship between leverage and return on equity of listed DMBs in Nigeria.

\section{DISCUSSION OF FINDINGS}

The Findings of the study partly support the agency cost theory. While there is evidence to support the non-monotonic relationship (positive relationship for small values and negative for large values of leverage ratios) prediction of the theory; the positive linear relationship prediction of the theory is not supported by empirical evidence. This position aligns with the results obtained by Skopljak (2012) and Ganiyu (2015). This implies that the use of debt finance by DMBs in Nigeria does not significantly improve performance. On the contrary, the increasing use of debt by DMBs becomes detrimental to performance. The postulation of the agency cost theory to explain this behaviour is that the use of debt finance creates opportunities for shareholders to shift risks to debt holders. This finding may not be unconnected with the high leverage employed by Nigerian DMB's.

The negative linear relationship found between leverage and profit efficiency, even though insignificant, is inconsistent with other studies on Nigerian DMBs by Esiemogie et al. (2014), Adesina et al. (2015) Shaba et al. (2016). These studies found a positive significant linear relationship between leverage and bank performance. This inconsistency may be explained by the difference in the methodology applied. While the aforementioned studies employed traditional accounting measures as surrogates for firm performance, this study opted for profit efficiency as a proxy for firm performance. Interestingly, Velnampy \& Niresh (2012) 
found a negative linear relationship between leverage and bank performance using traditional accounting measures, albeit, the study employed Sri- Lankan data. The positive linear relationship, although insignificant, observed between leverage and return on equity thus lends credence to the robustness check employed by the study.

Return on equity has a positive linear relationship with leverage, though statistically insignificant, as observed from table 7. This is most likely a result of the tax shield enjoyed by banks arising from the use of debt finance over equity finance. The contrasting influence of leverage on profit efficiency and return on equity may be explained by the fact that the profit efficiency measure is not simply a measure of absolute profitability; but, also the efficiency with which such profits are achieved, given the inputs employed in generating such earnings. However, return on equity as a robustness check supports the results observed with profit efficiency in respect of the predicted non-monotonic relationship between leverage and bank performance.

\section{CONCLUSION AND RECOMMENDATIONS}

Based on the empirical examination of the study concepts and variables, it can be postulated that the use of debt financing as a tool to curb the excesses of managers may lead to short term benefits such as tax shield which improves annual accounting earnings. However, such high proportions of debt have negative implications in the long run for the bank's capacity to sustain such earnings at an efficient level; not to mention the risk of bankruptcy which increases with increases in debt proportions. Thus, either, the banks are constrained to employ more debt finance by the operating and regulating environment in which they carry out business, or they are simply oblivious to the net effect of employing such high levels of debt within their capital structures. Whatever the case, managers must be cautious of the implications of increasing leverage on bank performance.

The study makes the following significant recommendations in the light of the key findings already highlighted:

1. The CBN should as a matter of expediency place a cap on the proportion of debt finance DMB's in Nigeria can utilize within their capital structure. These authorized limits should be backed by law.

2. Shareholders should pay more attention to promoting good corporate governance as a means of curtailing agency conflicts and costs, rather than the use of debt instruments.

\section{References}

[1]. Abor, J. (2005). The effect of capital structure on profitability: An empirical analysis of listed firms in Ghana. Journal of Risk Finance, 6(5), 438-445.

[2]. Adesina, J. B., Nwidobie, B. M., \& Adesina, O. O. (2015). Capital structure and financial performance in Nigeria. International Journal of Business and Research, 05(02), 21-31.

[3]. Aggarwal, R., \& Kyaw, N. A. (2010). Capital structure, dividend policy, and multinationality: Theory versus empirical evidence. International Review of Financial Analysis, 19(2), 140-150.

[4]. Al- Najjar, B. (2011). The inter-relationship between capital structure and dividend policy: Empirical evidence from Jordanian data. International Review of Applied Economics, 25(2), 209-224.

[5]. Ali, S. M., Salleh, N. M., \& Hassan, M. S. (2008). Ownership structure and earnings management in Malaysian listed companies: The size effect. Asian Journal of Business and Accounting, 1(2), 89-116.

[6]. Amin, S., \& Jamil, T. (2015). Capital structure and firm performance: Evidence from cement sector of Dhaka Stock Exchange. Journal of Finance and Banking, 13(1), 29-42.

[7]. An, Z., Li, D., \& Yu, J. (2016). Earnings management, capital structure, and the role of institutional environments. Journal of Banking and Finance, 68, 131-152.

[8]. Azhagaiah, R., \& Gavoury, C. (2011). The impact of capital structure on profitability with special reference to IT industry in India. Managing Global Transitions, 9(4), 371-392.

[9]. Balakrishnan, S., \& Fox, I. (1993). Asset specificity, firm heterogeneity and capital structure. Strategic Management Journal, 14(1), 3-16.

[10]. Bancel, F., \& Mittoo, U. (2004). Cross-country determinants of capital structure choice: A survey of European firms. Financial Management, 33(4), 103-132.

[11]. Barth, J. R., Caprio, G. J., \& Levine, R. (2004). Bank regulation and supervision: what works best? Journal of Financial Intermediation, 13(2), 205-248.

[12]. Berger, A. N., \& Bonaccorsi, E. (2006). Capital structure and firm performance: A new approach to testing agency theory and an application to the banking industry. Journal of Banking \& Finance, 30(4), 1065-1102.

[13]. Bokpin, G. A. (2009). Macroeconomic development and capital structure decisions of firms: Evidence from emerging market economies. Studies in Economics and Finance, 26(2), 129-142.

[14]. Bokpin, G. A., \& Arko, A. C. (2009). Ownership structure, corporate governance and capital structure decisions of firms: Empirical evidence from Ghana. Studies in Economics and Finance, 26(4), 246-256.

[15]. Bradley, M., Jarrell, G. A., \& Kim, E. H. (1984). On the existence of an optimal capital structure: Theory 
and evidence. Journal of Finance, 39(3), 857-878.

[16]. Brealy, R., Myers, S., \& Allen, F. (2001). Principles of corporate finance. McGraw- Hill.

[17]. Brigham, E. F., \& Houston, J. F. (2007). Fundamentals of financial management. Thomson South-Western.

[18]. Butt, S., \& Hasan, A. (2009). Impact of ownership structure and corporate governance on capital structure of Pakistani listed companies. International Journal of Business \& Management, 4(2), 50-57.

[19]. Dada, F. B. (2014). The effects of capital structure on the financial performance of large industrial listed firms in Nigeria. Developing Country Studies, 4(10), 121-131.

[20]. Erotis, N., Vasilliou, D., \& Ventoura-Neokosmidi, Z. (2011). How firm characteristics affect capital structure: An empirical study. Managerial Finance, 33(5), 321-331.

[21]. Frank, Z. M., \& Goyal, K. V. (2003). Testing the pecking order theory of capital structure. Journal of Financial Economics, 67(2), 217-218.

[22]. Frank, Z. M., \& Goyal, K. V. (2009). Capital Structure decisions: Which factors are reliably important? Financial Management, 38(1), 1-37.

[23]. Ganiyu, O. Y. (2015). Dynamic analysis of the impact of capital structure on firm performance in Nigeria. De Montfort University.

[24]. Githire, C. (2015). Effects of capital structure on financial performance of firms in Kenya: evidence from Firms listed at the Nairobi securities exchange. International Journal of Economics, Commerce and Management, III(4), 1-10.

[25]. Guney, Y., Li, L., \& Fairchild, R. (2011). The relationship between product market competition and capital structure in Chinese listed fims. International Review of Financial Analysis, 20(1), 41-51.

[26]. Gwatidzo, T. (2009). Determinants of capital structure in Africa. University of Witwaterstrand.

[27]. Hackbarth, D., Miao, J., \& Morellec, E. (2006). Capital structure, credit risk, and macroeconomic conditions. Journal of Financial Economics, 82(3), 519-550.

[28]. Harris, M. R., \& Raviv, A. (1991). The theory of capital structure. Journal of Finance, 46(1), 297-355.

[29]. Hassan, L., \& Samour, S. (2016). Capital structure and firm performance: Did the financial crisis matter?A cross-industry study. Uppsala University.

[30]. Hassan, U. S., \& Miko, U. N. (2015). Impact Assessment of Bank Consolidation on the Performance of Commercial Banks in Nigeria. Acta Universitatis Danubius. Economica, 11(5), 30-44.

[31]. Holland, J., \& Foo, U. (2003). Differences in environmental reporting practices in the UK and the US: The legal and regulatory context. British Accounting Review, 35(1), 1-18.

[32]. Huang, G., \& Song, F. M. (2002). The Financial and operating performance of China's newly listed H firms. Pacific-Basin Finance Journal, 13(1), 53-80.

[33]. Idode, P. E., Adeleke, T. M., Ogunlowore, A. J., \& Ashogbon, O. S. (2014). Influence of capital structure on profitability: Empirical Evidence from listed Nigerian banks. IOSR Journal of Business and Management, $16(11), 22-28$.

[34]. Jensen, M. C.,\& Meckling, W. H. (1976). The theory of the firm, managerial ownership, agency cost and ownership structure. Journal of Financial Economics, 3(4), 305-361.

[35]. Jensen, C. M. (1986). Agency costs of free cash flow, corporate finance and takeovers. American Economic Review, 76(2), 332-329.

[36]. Jiraporn, P., \& Gleason, K. C. (2007). Capital structure, shareholder rights, and corporate governance. Journal of Financial Research, 30(1), 21-23.

[37]. Jiraporn, P., Kim, J., Kim, Y. S., \& Kitsabunnarat, P. (2012). Capital structure and corporate governance quality: Evidence from institutional shareholder services (ISS). International Review of Economics \& Finance, 22(1), 208-221.

[38]. Jong, A. D., Kabir, R., \& Thu, T. (2008). Capital structure around the world : The roles of firm- and countryspecific determinants. Journal of Banking and Finance, 32(9), 1954-1969.

[39]. Kovenock, D., \& Phillips, G. (1995). Capital structure and product-market rivalry: How do we reconcile theory and evidence? American Economic Review, 85(2), 403-408.

[40]. Margaritis, D., \& Psillaki, P. (2010). Capital structure, equity ownership and firm performance. Journal of Banking \& Finance, 34(3), 621-632.

[41]. Maudos, J., Pastor, J. M., Perez, F., \& Quaseda, J. (2002). Cost and profit efficiency in European banks. Journal of International Financial Markets, Institutions and Money, 12(1), 33-58.

[42]. Mirza, A. S., \& Javed, A. (2013). Determinants of financial performance of a firm: Case of Pakistani stock market. Journal of Economics and International Finance, 5(2), 43-52.

[43]. Mirza, H., \& Azfa, T. (2010). Ownership structure and cash flows as determinants of corporate dividend policy in Pakistan. International Business Research, 3(3), 210-221.

[44]. Modigliani, F., \& Miller, M. (1958). The cost of capital, corporation finance and the theory of investment. American Economic Review, 48(3), 261-297.

[45]. Modigliani, F., \& Miller, M. (1963). Corporate income taxes and the cost of capital: A correction. American Economic Review, 53(3), 433-443.

[46]. Modugu, K. P. (2013). Capital structure decision: An overview. Journal of Finance and Bank Management, $1(1), 14-27$.

[47]. Morellec, E., Nikolov, B., \& Schurhoff, N. (2012). Corporate governance and capital structure dynamics. 
The Journal of Finance, 67(3), 803-848.

[48]. Morri, G., \& Cristanziani, F. (2009). What determines the capital structure of real estate companies?: An analysis of the EPRA/NAREIT Europe index. Journal of Property Investment \& Finance, 27(4), 318-372.

[49]. Muturi, W. (2015). Effects of capital structure on financial performance of firms in Kenya: evidence from firms listed at the Nairobi Securities Exchange. International Journal of Economics, Commerce and Management, III(4), 1-10.

[50]. Myers, S. C., \& Majluf, N. S. (1984). Corporate financing and investment decisions when firms have information that investors do not have. Journal of Financial Economics, 13(2), 187-221.

[51]. Naz, I., Bhatti, K., \& Ghafoor, H. H. (2011). Impact of firm size and capital structure on earnings management: Evidence from Pakistan. International Journal of Contemporary Business Studies, 2(12), 2231.

[52]. Nwaolisa, E., \& Chijindu, A. (2016). The impact of financial structure on firm performance: A study of Nigeria Agricultural and Healthcare Sector. Archives of Current Research International, 4(1), 1-26.

[53]. Okoye, U. L., Adetiloye, A. K., \& Evbuomwan, O. G. (2017). Impact of banking consolidation on the Performance of the banking sector in Nigeria. Journal of Internet Banking and Commerce, 22(1), 2-15.

[54]. Olowe, R. A. (2011). Financial management: concepts, financial system and business Frame (3rd ed.). Ibadan University Press.

[55]. Öztekin, Ö., \& Flannery, M. J. (2012). Institutional determinants of capital structure adjustment speeds. Journal of Financial Economics, 103(1), 88-112.

[56]. Pandey, I. M. (2010). Financial Management (10th ed.). Vikas Publishing Home PVT Ltd.

[57]. Psillaki, M., \& Daskalakis, N. (2009). Are the determinants of capital structure country or firm specific ? Journal of Small Business Economics, 33(3), 319-333.

[58]. Rahmani, S., \& Akbari, M. A. (2013). Impact of firm size and capital structure on earnings management: Evidence from Iran. World of Sciences Journal, 1(17), 59-71.

[59]. Saad, N. M. (2010). Corporate governance compliance and the effects to capital structure in Malaysia. International Journal of Economics and Finance, 2(1), 105-114.

[60]. Shaba, Y., Yaaba, N. B., \& Abubakar, I. (2016). Capital structure and profitability of deposit money banks: Empirical evidence from Nigeria. European Journal of Business and Management, 8(23), 110-121.

[61]. Shubita, M. F., \& Jordan, A. (2012). The relationship between capital structure and profitability. International Journal of Business and Social Science, 3(16), 104-112.

[62]. Skopljak, V. (2012). Capital structure and firm performance in the financial sector: Evidence from Australia. Asian Journal of Finance \& Accounting, 4(1), 278-298.

[63]. Stanton, P., \& Stanton, J. (2002). Corporate annual report: Research perspectives used. Journal of Accounting, Auditing and Accountability, 15(4), 478-500.

[64]. Velnampy, T., \& Niresh, A. J. (2012). The relationship between capital structure \& profitability. Global Journal of Management and Business Research, 12(13), 66-73.

[65]. Vijayakumar, A., \& Karunaiathal, A. (2014). The effect of capital structure on profitability -An empirical analysis of Indian paper industry. International Research Journal of Business and Management., VII(13), $28-42$.

[66]. Wilmshurst, D. W., \& Frost, G. R. (2000). Corporate environmental reporting. A test of legitimacy theory. Accounting, Auditing and Accountability Journal, 13(1), 10-26.

[67]. Zeitun, R., \& Tian, G. (2007). Capital structure and corporate performance : Evidence from Jordan. Australasian Accounting Business \& Finance Journal, 1(4), 40-53. 